
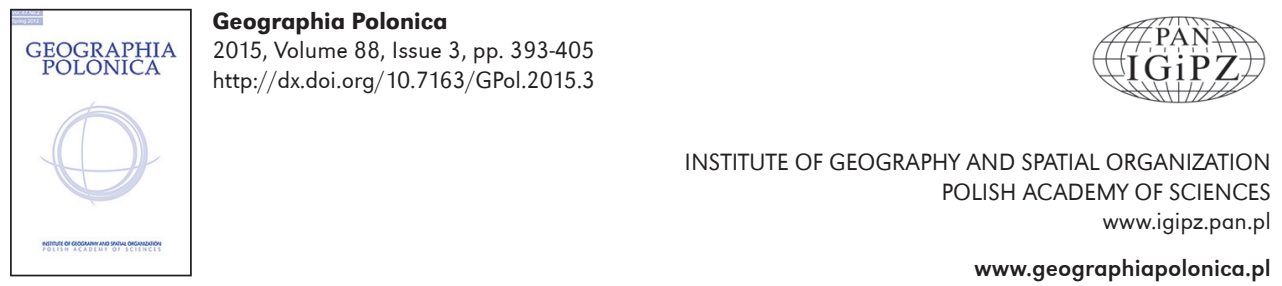

\title{
BED MATERIAL EXTRACTION AND ITS EFFECTS ON THE FORMS AND PROCESSES OF THE LOWER BALASON RIVER IN THE DARJEELING HIMALAYAS, INDIA
}

\section{Lakpa Tamang • Deepak Kumar Mandal}

North Bengal University

Department of Geography \& Applied Geography

P.O. NBU, Rajarammohanpur, District Darjeeling - 734 013, West Bengal: India

e-mails: tamanglakpa@gmail.com・dkmandalnbu@gmail.com

\begin{abstract}
High intensity rains bring about landslides and high surface run-off in the upper catchment of the Balason River. Huge quantities of weathered materials as sediment load are being deposited in the river's lower course. The extent and intensity of this bed material extraction have taken such a toll that immediate attention is necessary to reduce the associated effects on the forms and processes of the Balason River's lower course. In this paper, an attempt has been made to closely analyse the prevailing effects of human interference noticed by the authors during this study. The methodology adopted during this study is field based. The changing cross sections and fluvial characteristic of the river were continuously observed. The extraction of bed materials was done directly from the riverbed and from adjacent flood plains and also from terraces. The extractions are responsible for the prevailing bed erosion and channel diversions because extraction pits are what are left behind. In the long term, if not controlled, the effects would be detrimental to the entire fluvial characteristics of the river.
\end{abstract}

\section{Key words}

Balason River $\bullet$ bed erosion $\bullet$ bed material extraction $•$ Darjeeling Himalayas $\bullet$ scouring and filling

\section{Introduction}

In the Darjeeling Himalayas, the heavy, concentrated annual rainfall (above $1000 \mathrm{~mm}$ ) causes high surface erosivity and frequent landslides. These conditions caused the Balason River (Fig. 1) to carry large quantities of bed material to the lower course of the river.
These materials are corrosive in nature and are easily extracted directly from the riverbed. The materials do not require much processing. Extracting the materials could provide an ideal source for developing construction industries in the region. However, extensive extraction in an unplanned and unorganized manner is disturbing the channel forms 
and processes of the Balason River (Fig. 2). In order to adjust to the locally steeper gradients caused by the extraction pits, the stream power has increased, resulting into bed erosion. Similarly, the extraction taking place near the bank, and the diversion of the main flow, have increased the height of the banks and are wearing away the exposed banks during monsoon high flows.

The Balason River has been an important river in the context of fluvio-geomorphological studies carried out in this region. The dynamic nature and also the anthropogenic transformation where land use and the region's carrying capacity have changed, have focused attention on the the river. Dutta (1995) studied the changes in river behaviour, while focusing on: the channel adjustment under human modifications, gravel extraction from the river, raising the embankments, and channel alterations under the bridges. Jana and Dutta (1995) carried out a detailed study of the causes and rate of bank erosion along the right bank of the Balason River, the relationship with the lithological composition of the bed and bank materials, and the impact on the riparian dwellers. The quantitative characteristics of the longitudinal and transversal profiles of the Balason River were also studied by De (2010) to show the intermittent uplifts of the Himalayas interrupting the smooth running of a cycle of erosion. His study also covered the changing nature of the channel bed, and specially, the impact of huge flood waters on the channel form. Rinadli et al. (2005) have sufficiently documented cases selected from published studies on the effects of sediment mining or bed material extraction on alluvial rivers like Cache Creek of California studied by Collins and Dunes (1997) and Kondolf(1997); the Arno River, central Italy, studied by Billi and Rinaldi (1997), Rinaldi and Simon (1998) and Agnelli et al. (1998); the Lower Manawatu River, New Zealand, studied by Page and Heerdegen (1985) and Collins and Dunne (1990); and the Jarama River, central Spain, studied by Uribelarrea et al. (2003). In most of these studies, incision followed by damage to bridges, and lateral instability have been noticed as common effects. Hence, extraction of bed material from an active riverbed may trigger changes in many factors governing fluvial processes, disturb the sediment balance, and alter the erosion and sedimentation patterns (Lopez 2004). The extraction of bed materials is also responsible for infringing on channel adjustments between the channel geometry and its sediment capacity (Martin-Vide et al. 2010). Similarly, Bravard et al. (2013) stated that due to the extraction of sand and gravel, a local incision of 1 to $3 \mathrm{~m}$ threatening infrastructure has been noticed in some reaches of the lower Mekong River.

\section{Objective and methodology adopted for the study}

The main objective of this paper was to study the principal effects of the bed-material extraction on the channel forms and processes along the lower course of the Balason River. The continuous extraction of bed materials is responsible for bed erosion. With the help of surveyed cross-sections, we have noted the temporal and spatial extents of bed erosion. We have also analysed the changing channel processes in the form of scouring and filling and resultant hydraulic responses, so that there will be a better understanding of the prevailing fluvial characteristics of the lower Balason River.

To estimate the actual amount of bed material extracted from the river, the number of trucks carrying extracted materials from different sites have been recorded during the field surveys. This information was compiled with the official records of check posts and concerned offices, from 2002 through 2010. The seasonal changes in the morphological characteristics have been surveyed at a $4.2 \mathrm{~km}$ stretch (Fig. 3), where there was maximum extraction with cross-sections at every $200 \mathrm{~m}$, both during pre-monsoon (March-May) and post-monsoon periods (November-January). The surveying took place from 2008 to 2010 with the help of Central Water Commission 
(CWC) datum of $119 \mathrm{~m}$. The data relating to the hydrological and fluvial characteristics, such as discharge, velocity, cross-sections, and sediments were measured directly from the field and also have been compared and validated with the data collected from the CWC Gauging \& Discharge Site, Matigara.

\section{The study area}

The funnel-shaped Balason basin has its source from a place named Lepchajagat, located on the Ghum-Simana ridge at an altitude of $2361 \mathrm{~m}$ a.s.l. It is the major right bank tributary of Mahananda River covering an area of $367.42 \mathrm{~km}^{2}$. The Balason, being a perennial river, has a total length of about $48.4 \mathrm{~km}$ of which $24.27 \mathrm{~km}$ is in the hills and remaining $24.13 \mathrm{~km}$ flows through the plain region and finally mixes with the Mahananda River near the town of Siliguri. The right bank tributaries of the Balason River are Pulungdung Khola, Rangbang Khola, Marma Khola, Manjwa Jhora, and Dudhia Jhora. The left bank tributaries are Bhim Khola, Rangmuk
Khola, Pachhim Khola, Rinchigtong Khola, and Ghatta Hussain Khola. The Balason River starts its lower course at an altitude of $305 \mathrm{~m}$ a.s.l. (Fig. 1) and from this area onwards, mostly transportation and deposition by the river take place. In its lower course, the river is joined by Rakthi Khola, Rohini Khola, Panighata Khola, Chenga, Manjha, etc.

The Balason basin lies in a geologically young, fragile region. There are metamorphic rocks such as gneiss, schists, and phyllites, which are intensively weathered, fractured, and jointed, making the rocks vulnerable to slope instability. The basin does not follow the law of absolute relief and slope frequency distribution, since maximum slope zones fall between $800-2200 \mathrm{~m}$ a.s.I. with a relative relief value of $300-500 \mathrm{~m}$. These figures indicate the youth stage of the basin. The annual maximum rainfall is $4629 \mathrm{~mm}$ and the annual average rainfall is $1750 \mathrm{~mm}$. Rampant deforestation has taken place. These factors makes the area highly vulnerable to soil erosion and landslides which choke the streams and lead them to change courses.

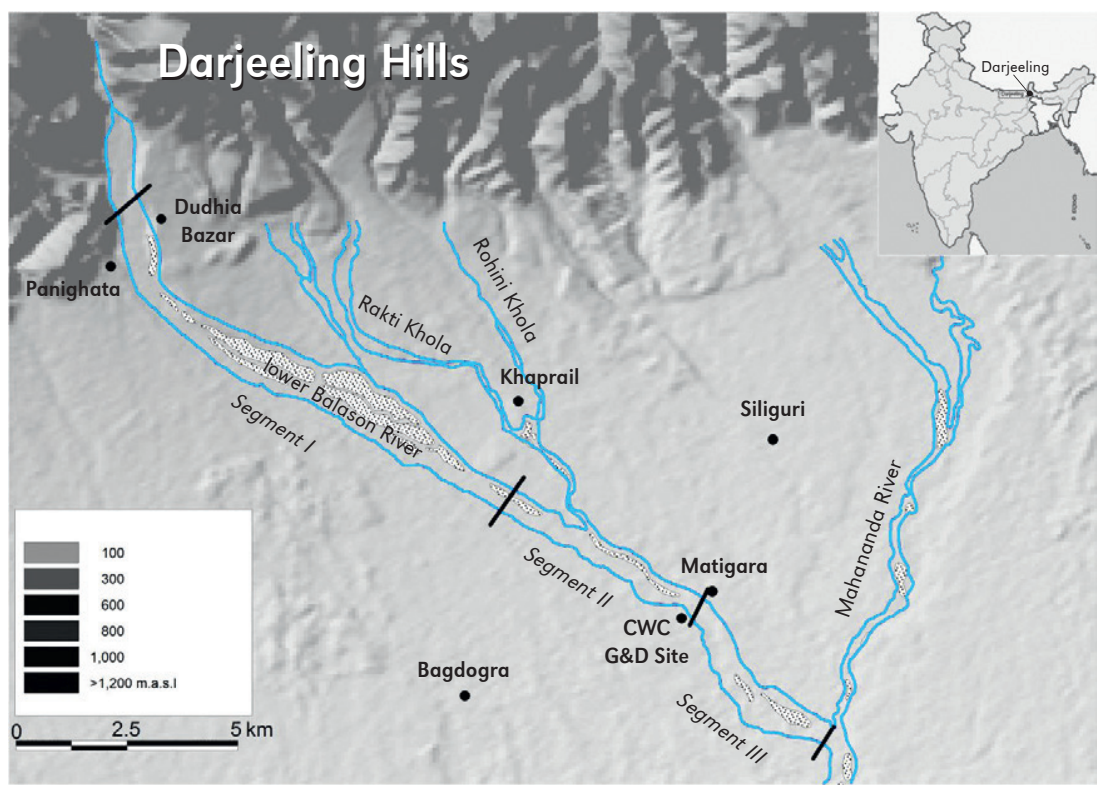

Figure 1. Location of the study area with the demarcation of the segments of bed material extraction along the lower Balason River 

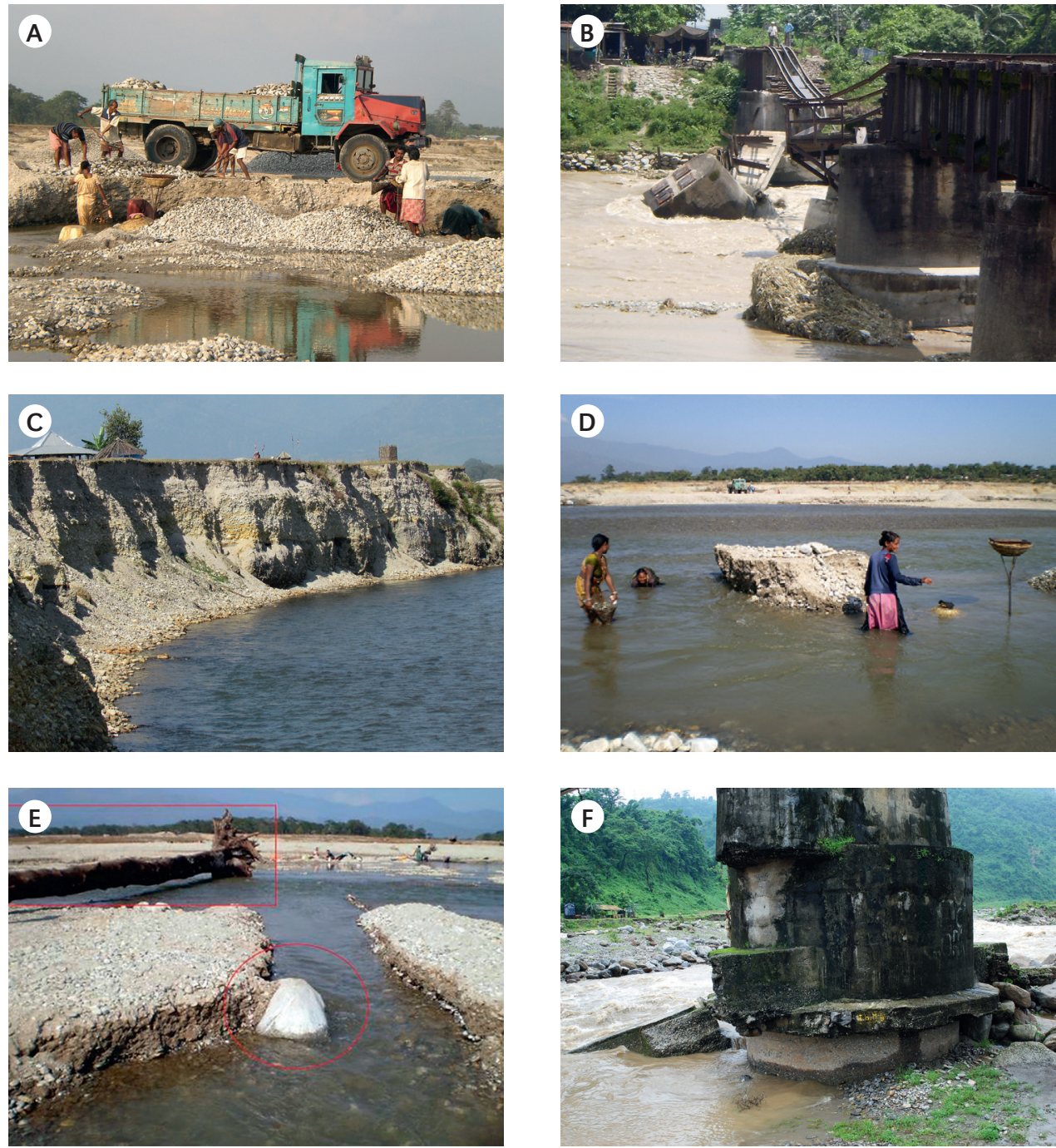

Figure 2. A - Bed material extraction from the riverbed in segment II; B - Damage of Railway Bridge downstream of N.H 31, in 2009; C - Exposed retreating banks upstream of N.H 31; D - Extraction of bar deposits upstream of N.H 31; E - Tree trunk and big boulder exposed due to bed incision at extraction site of segment II; F - Bridge pier at upper piedmont segment along the lower Balason River

\section{Bed material extraction in the lower course of the Balason River}

The extraction of bed materials along the lower Balason River began just after the river shifted its course into the present position. The present river is said to have migrated in the past, completely deserting the old course to occupy its present valley. In this way, the Balason divided itself into two channels; the new Balason and the old or the Buri Balason near Tiharana Tea garden area. In old records, in Survey of India topographical maps, cadastral maps, different scientific articles etc. it has been found that the region was previously known for its fertile 
agricultural land and widespread forest cover (Tamang 2013). The loss of agriculture lands forced the local inhabitants to start extracting the bed materials as an alternative source of livelihood. Initially, only large-sized gravels and boulders were quarried. As demand increased, extraction of other grades of bed materials began. During 2008-2010, according to the official records of the District Land and Land Reform Office in Darjeeling, India, there were a total of 37 Quarry Permits and 21 of these permit holders operated at the lower course of the Balason riverbed (Tamang \& Mandal 2010).

Extraction of bed materials along the lower course of the Balason River is mostly dependent upon the size, amount, and quality of available bed materials. On the extraction sites, bed materials of up to $2 \mathrm{~m}$ are extracted during the dry season, and the larger boulders (400-200 $\mathrm{mm}$ in size) are collected which are broken into smaller sizes ranging between 75 to $90 \mathrm{~mm}$ in diameter. During the monsoon period, mostly larger boulders and gravel brought down by the flow, are extracted near the banks. During this period, the in-stream extractions are carried out to a lesser extent, as the river becomes inaccessible because of the increased channel flow. Based on the information collected during extensive field surveys, the authors have divided the whole lower course into 3 important segments (Fig. 4). The divisions were made on the basis of size and quantity of the extracted volume from different sites. The divisions are:

SEGMENT I: In this segment extending up to $8 \mathrm{~km}$ downstream from the Dudhia Bridge, large-sized boulder ranging up to $1 \mathrm{~m}$ in diameter predominate. The extraction of larger-sized gravels and boulders are common in this section. Using human strength, the boulders are broken down into different sizes according to the demand of the market.

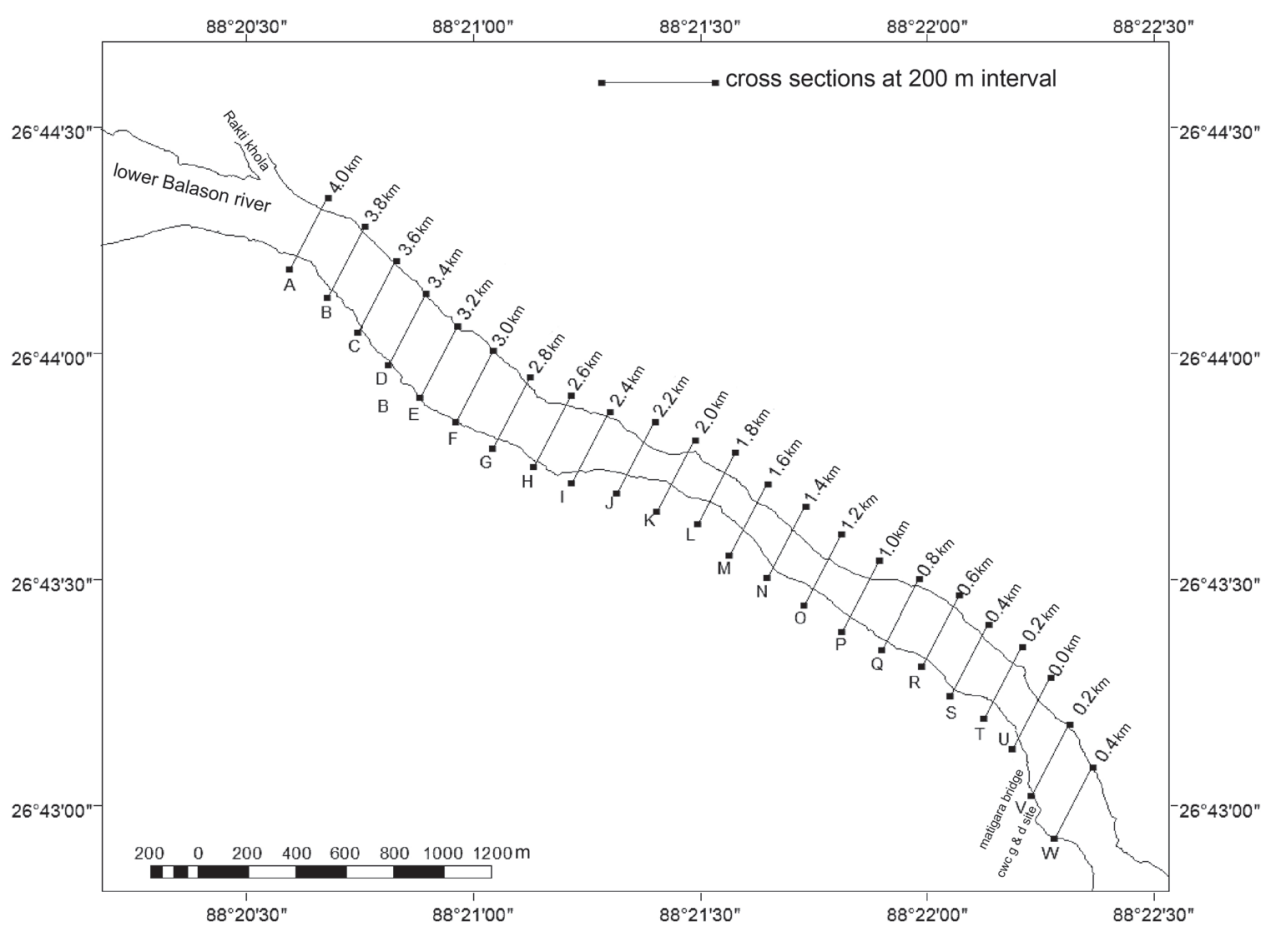

Figure 3. Location of the surveyed cross-sections (at 200 m intervals) in segment II of the lower Balason River 
The extracted volumes from this segment are mainly used for roads (sloping) as well as for embankments and bridge construction. The important sites in this zone are Dudhia, Panighata, M. M. Terai, Bauni Bhitar Chhat, Dhemal, Tarabari, and Gouri.

SEGMENT II: The total length of this segment is about $9 \mathrm{~km}$. It extends up to the Matigara Bridge. Due to a gradual decrease in sediment size, boulders ranging from 300 to $50 \mathrm{~mm}$ in diameter are extracted. Huge amounts of medium to small-sized gravel along with both coarse and fine grained sand are extracted. At the extraction sites, the extracted materials are processed manually, and there are also processing centres (Kasari) where bed materials are processed into different grades with the help of mechanically operated sieves. Due to the accessibility of N.H 31 and also other well-connected local roads, this segment has the largest number of extraction sites and also the extracted volume is the highest in the whole stretch.

SEGMENT III: In the remaining length of about $7 \mathrm{~km}$, downstream from Matigara
Bridge, the extraction of smaller sized gravel, pebbles, and sand, predominates. At the extraction sites, mostly in-stream bed materials are manually extracted, washed, and sieved simultaneously. What is mainly sand extraction, is done on a large scale (Fig. 2A). The important sites are Jitu, Mathapari, Kalam, and Kauakhali.

\section{Effects of bed material extraction on the forms of the lower Balason River}

The morphological characteristic of the Balason River in its lower course, shows a marked variation in bed elevation. This variation may be attributed to the extensive extraction of bed materials not only from the river beds, but also from adjacent floodplains and from terraces. During the present study, it has been observed that the extent of extraction increases as the river proceeds downstream. In the middle segment of the river, the maximum volume of bed materials are being extracted.

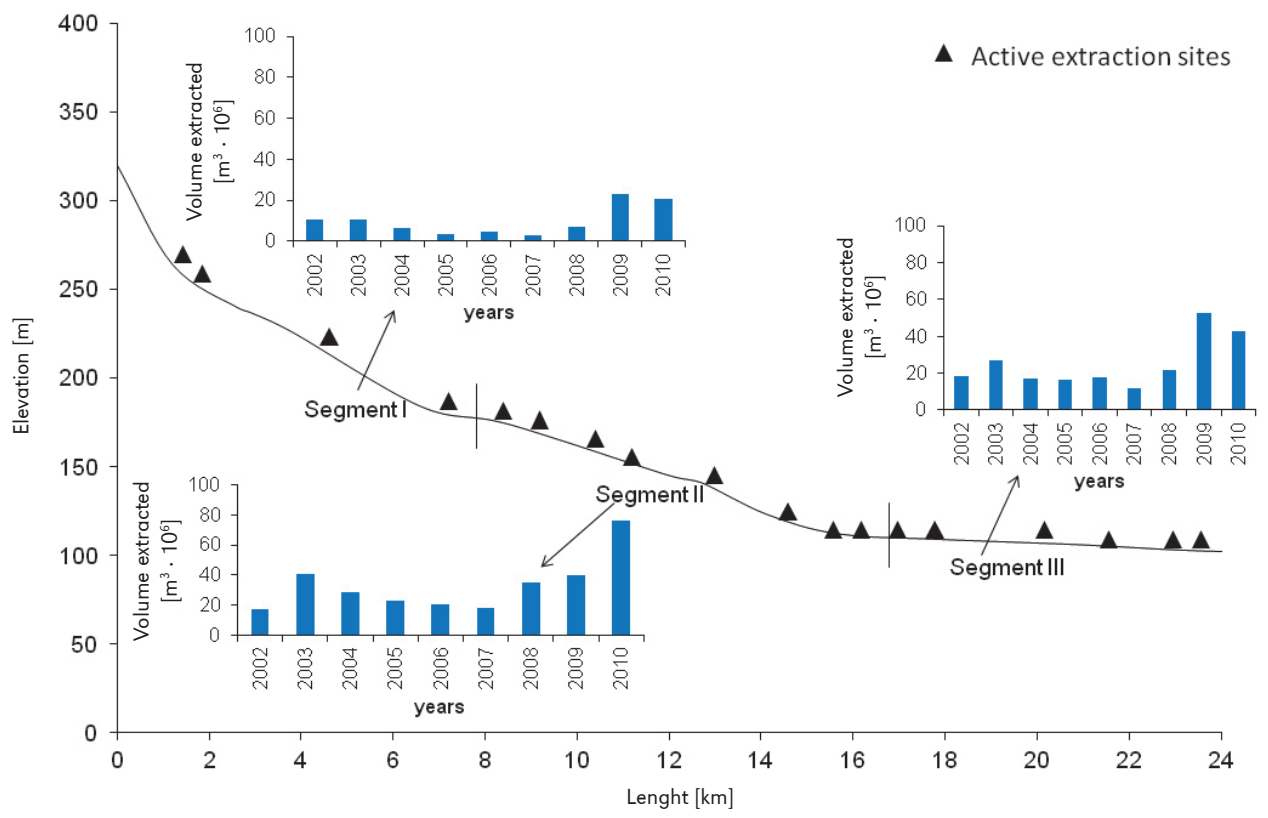

Figure 4. Total volume of extracted bed materials (in $\mathrm{m}^{3} \cdot 10^{6}$ ) calculated based on field and official records from different extraction sites during 2002-2010 
The mean annual bed elevation also revealed the variability in scouring and filling by the river during the study period. In 2008, the mean bed elevation was $118.275 \mathrm{~m}$ which decreased to $118.081 \mathrm{~m}$ in 2009, but in 2010 it again increased to $118.123 \mathrm{~m}$ (Fig. 5). In 2008, more than 50\% of the area experienced scouring, mainly due to the excessive volume of bed materials extracted from this stretch. But in 2009 and 2010, the filling of the previous lowered channel bed substantially increased the bed elevation in almost all the sections except for some scouring that could be noticed in the upper sections (3.800, 3.200 and $0.200 \mathrm{~km}$ sections). Such annual changes are highly variable in almost every section of the selected stretch of the lower Balason River.
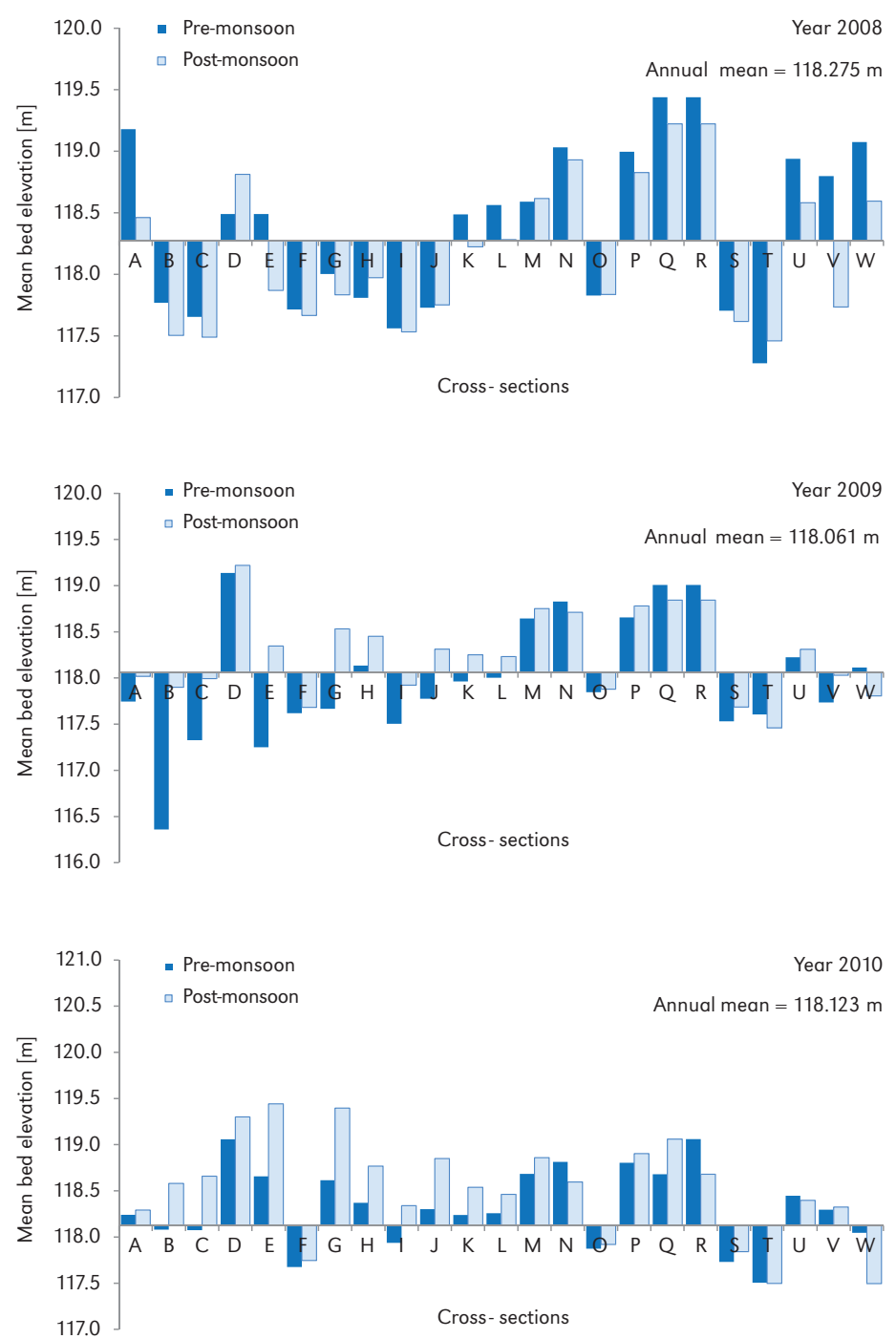

Figure 5. The annual variability in mean bed elevation $(\mathrm{m})$ during pre-monsoon and post-monsoon from the annual mean bed elevation during 2008-2010 
The annual scouring and filling by the river has been maintained to some extent, but the bed material extractions have caused bed erosion. The difference in mean bed elevations during pre-monsoon and post-monsoon conditions from the annual mean bed elevation reveals that bed erosion has occurred in all three years. There was a maximum erosion of $0.905 \mathrm{~m}$ at $0.200 \mathrm{~km}$ (cross-section T) in 2008, $1.149 \mathrm{~m}$ at $3.800 \mathrm{~km}$ (cross-section B) during 2009, and $0.992 \mathrm{~m}$ also in 2010 (Fig. 6). This clearly indicates that the effect of a continuous extraction of bed materials from the same place, have been creating extraction pits of more than $2.000 \mathrm{~m}$ deep. These pits have increased the channel gradient and consequent bed erosion, upstream and downstream of such extraction pits. Also, the tree trunks from the previously existing forest which were buried under the riverbed are now being exposed due to prolonged extraction on the channel bed. The exposure of the tree trunks are a clear indication of bed-erosion induced incision (Fig. 2E).
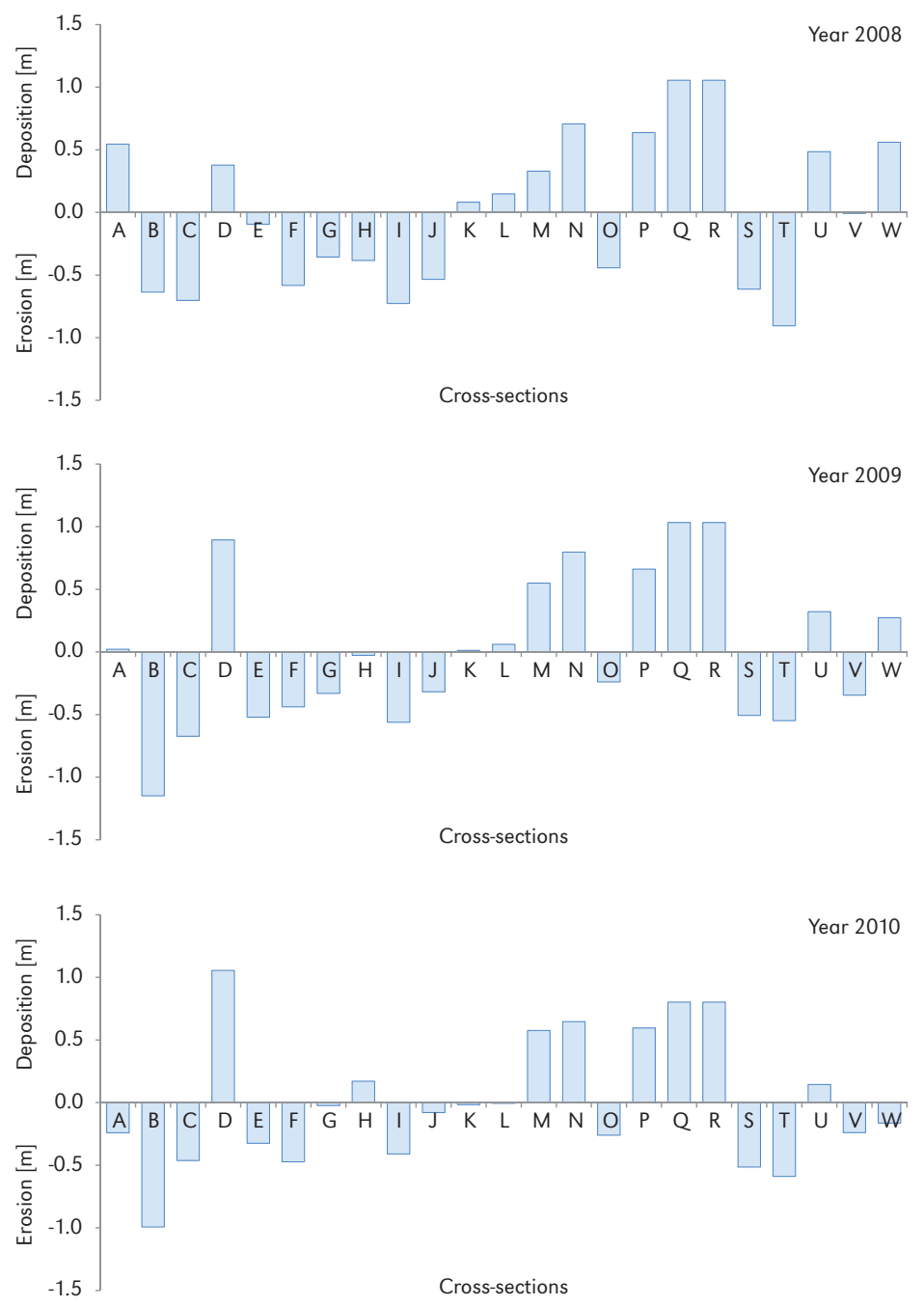

Figure 6. The annual erosion and deposition indicating the annual scouring and filling by the river in order to replenish the extracted volume at surveyed cross-sections during 2008-2010 
The study of the mean hydraulic radius, also considered as the measure of the efficiency of the channel (Schumm 1977), supports the fact that at sections with bed erosion, the hydraulic radius is higher compared to the sections with deposition replenishing the extraction volume. The maximum mean hydraulic radius of $1.238 \mathrm{~m}$ was computed for cross-section B $(3.800 \mathrm{~km})$ in 2008 , since bed erosion was noticed in this section both in 2008 and 2009 (Figs. 6 \& 7). The erosion was more than double the annual mean hydraulic radius $(0.574 \mathrm{~m})$ for the entire studied stretch. In 2009, the computed maximum mean hydraulic radius of $1.145 \mathrm{~m}$ occurred at cross-section $P(1.000 \mathrm{~km})$ with an annual mean of $0.537 \mathrm{~m}$. During 2010, the computed maximum mean hydraulic radius further decreased to $1.117 \mathrm{~m}$ at cross-section $\mathrm{V}$ ( $0.200 \mathrm{~m}$ below Matigara Bridge) with an annual mean hydraulic radius of $0.527 \mathrm{~m}$ for the entire studied stretch. It was revealed, that with a continuous increase of the mean hydraulic radius at a few sections, there was an increase in the channel velocity and energy, thus inducing bed erosion and an increase in the channel gradient.
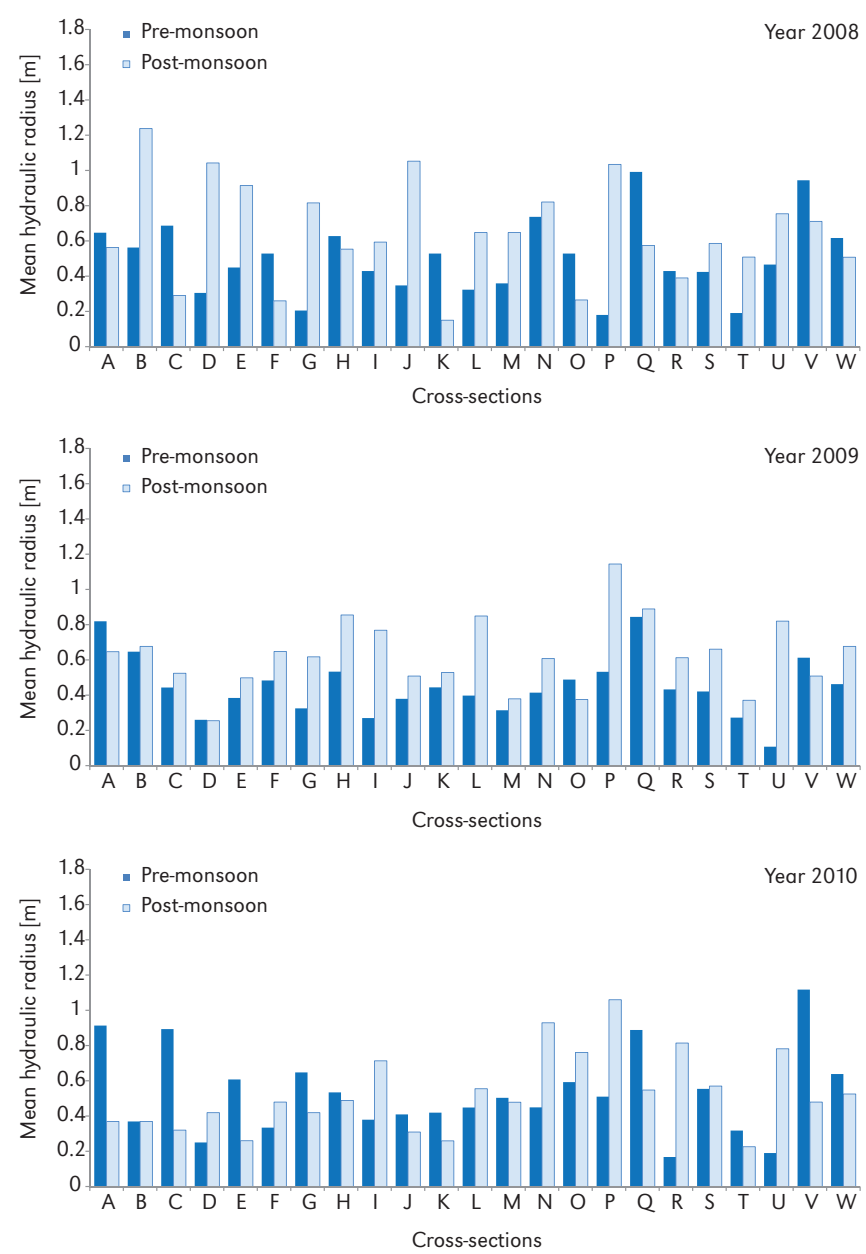

Figure 7. The mean annual hydraulic radius $(\mathrm{m})$ at surveyed cross-sections during pre-monsoon and post-monsoon conditions from 2008 to 2010 
The channel gradient variation between the cross sections is an indication of the channel erosion caused by prolonged bed-material extraction from the river bed. The lowering of bed elevations has caused the channel adjustments. There was an increase in the gradient, resulting in increased stream power and consequent bed erosion (Kondolf 1994). The cross-sections with maximum annual bed erosion (cross-sections B, E, R and U) had a steeper gradient which migrated both upstream and downstream annually (Fig. 8). This means that bed erosion also migrates depending on the active channel. Such migration is called "head cutting or knick point migration" according to Kondolf (1997).

\section{Effects of bed-material extraction on the processes of the lower Balason River}

The extraction of finer bed materials (mostly sand) increases channel efficiency and ultimately causes incision or bed lowering, leaving the coarser materials as pavements on the riverbed (Starkel \& Froehlich 2000). The annual minimum water level $(\mathrm{m})$ recorded at the CWC gauging site from 1990 to 2010 also shows a decreasing trend, which is largely due to the increase in the extraction rate after 2000 (Fig. 9). The volume of extraction has been much greater than the annual river replenishment volume. With an increase in the extraction rates the finer materials are transported downstream even during low flows. The monthly hydraulic mean depth from 2007 to 2010 (Fig. 10A) reveals that there exists an annual trend towards scouring and filling by the river. This occurrence takes place mostly during the monsoon period as the mean depth increases substantially during post-monsoon periods. Such conditions indicate that bed materials were higher during the post-monsoon period which induced the bed erosion and consequently increased the mean velocity (Fig. 10B).

Another effect of bed material extraction in the lower Balason River has been noticed in the mean monthly peak discharge from 2007 to 2010 (Fig. 11A). The lowering of the bed elevation and the occurrence of deep extraction pits, reduces the flow retention. This reduction attenuates the peak flows, but downstream the magnitude of inundation increases resulting in increased flooding (Rinaldi et al. 2005). The extensive extraction of bed materials from the lower Balason River has lowered the downstream transport of coarser sediments. The result is a lack of coarser sediments because the extraction pits act as pools for sediments. During high flow, only finer sediments are being transported to downstream segments. The replenished sediments brought by the river, fill such extraction-induced, temporary pools. This condition has lowered the roughness coefficient ( $\mathrm{n})$ of the riverbed, as noticed at the CWC Gauging \& Discharge Site, Matigara (Fig. 11B) from 2007 to 2010.

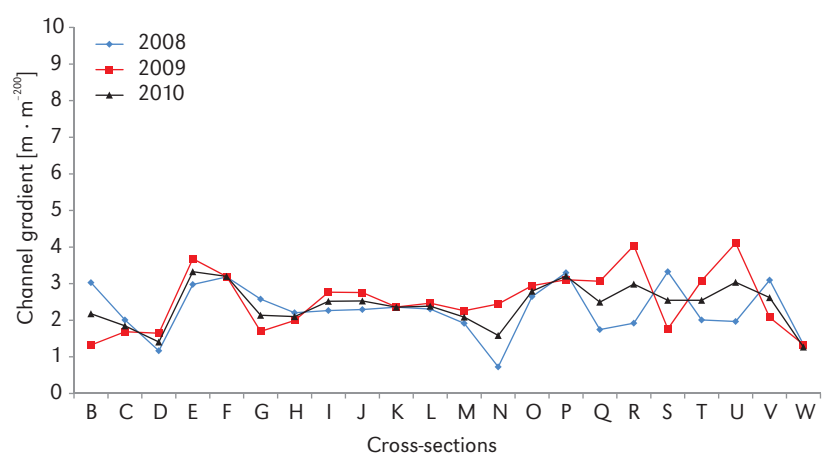

Figure 8. The mean annual channel gradient $(\mathrm{m})$ which migrates both upstream and downstream annually due to bed erosion at surveyed cross-sections during 2008-2010 


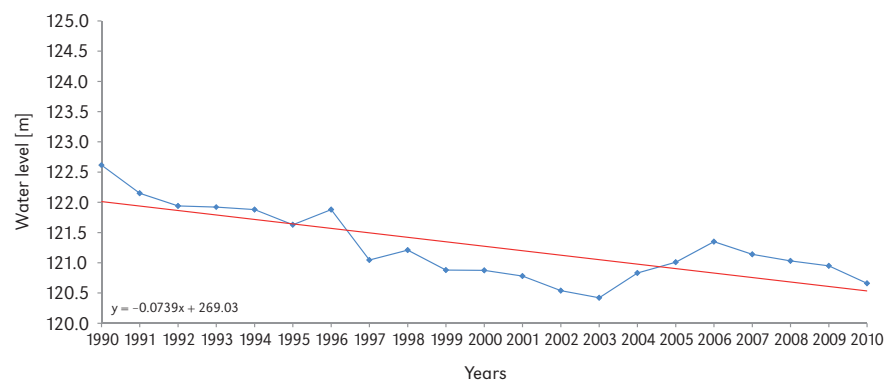

Figure 9. The bed incision trend of the lower Balason River based on the gradual decline of the annual minimum water level from 1990 to 2010 at the CWC Gauging \& Discharge Site, Matigara
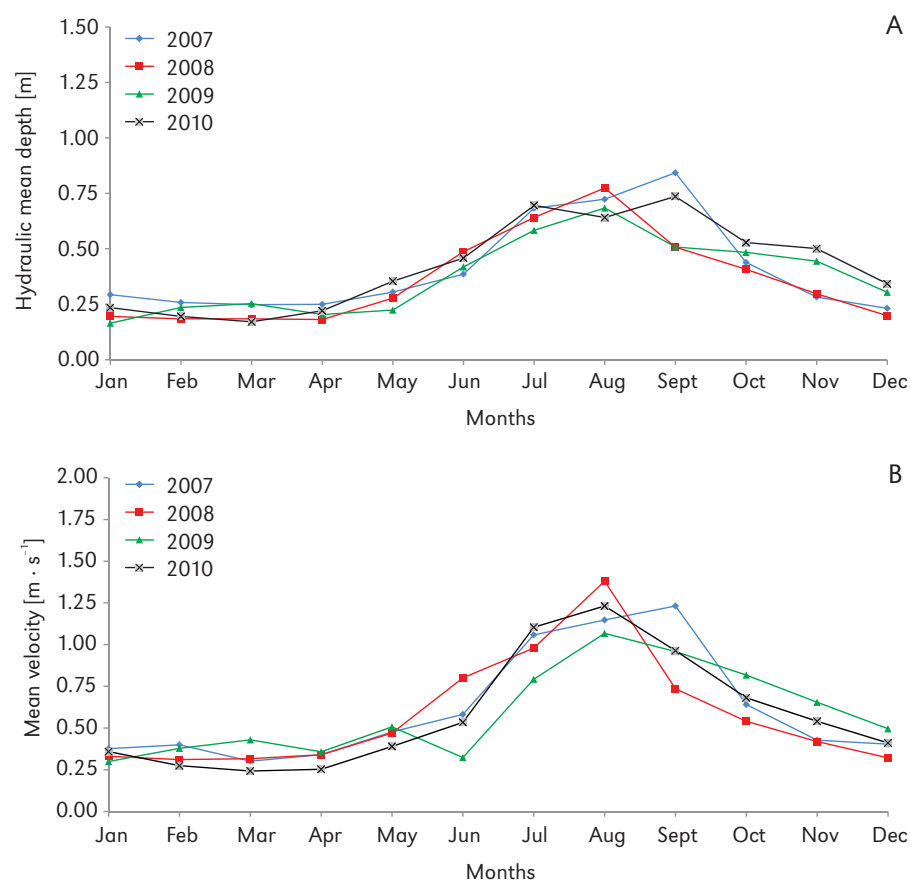

Figure 10. The monthly hydraulic mean depth (A) and the monthly mean velocity (B) from 2007 to 2010

\section{Conclusions}

The prolonged bed-material extraction from the lower Balason River has caused bed erosion. This erosion is migrating annually with variations in the channel gradient both upstream and downstream of the extraction sites. The river has been adjusting with changes in its morphology and with maximum coarse materials (gravel and boulders) being extracted from the river bed. The balance between sediment transport and the supply capacity of the river is being largely altered. The erosion in its upper segments has expanded beyond the margins of the lower plains. Human settlements near the banks and adjacent flood plains were established for easy access to the riverbed. Roads were also constructed near banks for transporting extracted bed materials. Both 

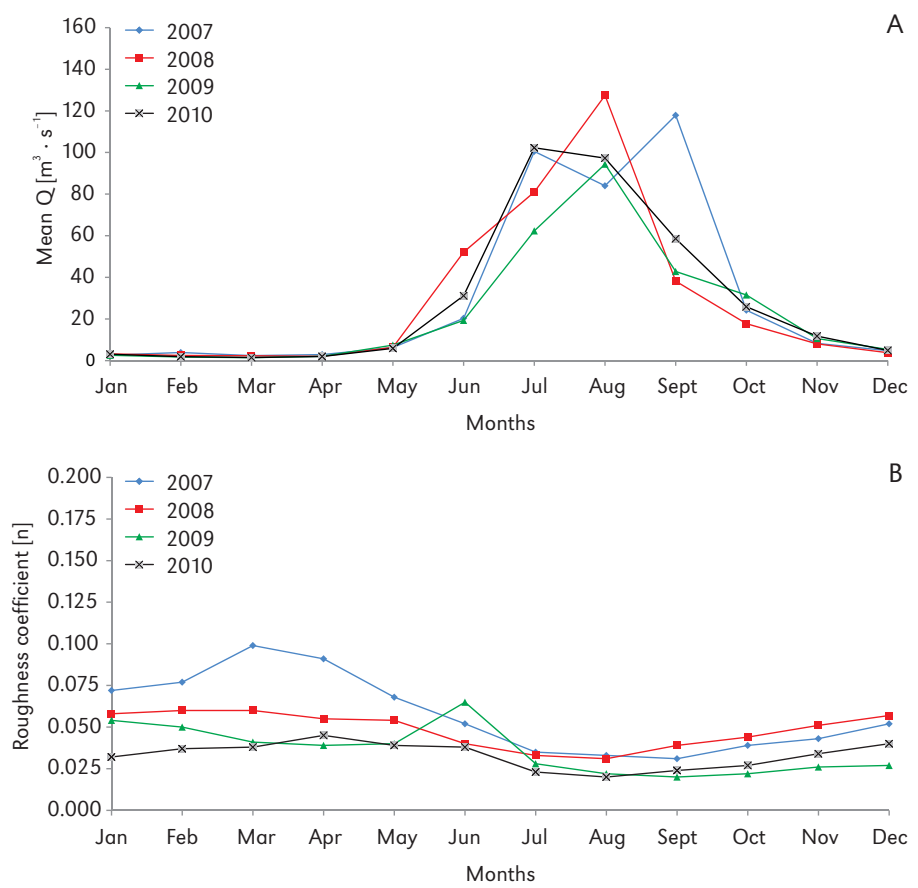

Figure 11. The monthly mean discharge (A) and the monthly mean roughness coefficient (B) of the lower Balason River during 2007-2010

of these factors have reduced the vegetation, triggering the exposed banks to retreat further (Fig. 2C). The adjustment by the river in the form of scouring and filling have also resulted in undercuttings below bridges (Fig. 2F) and embankments. The narrow channel width has caused flow retention. There has been destruction of permanent structures, as it happened on 18 August, 2009, when the two piers of the Railway Bridge located downstream of N.H 31 over the riverbed, was uprooted damaging the whole bridge (Fig. 2B). Such destruction is one of the effects of the river's adjustment under changing fluvial characteristics. Concerned authorities should implement a proper long-term management plan to reduce the effects of bed material extraction on the already degrading lower Balason River.

Editors' note:

Unless otherwise stated, the sources of tables and figures are the authors' on the basis of their own research. 


\section{References}

Bravard J.P., Goichot M., Stéphane G., 2013. Geography of sand and gravel mining in the lower Mekong River: First survey and impact assessment. EchoGeo, vol. 26, pp. 1-18.

DE S.K., 2010. A quantitative study of the longitudinal and cross-profiles (1989-1994) of the River Balason in the Darjeeling District of West Bengal. Indian Journal of Geomorphology, vol. 15, no. $1+2$, pp. 67-80.

DUTTA M., 1995. River Balason: A study of river behavior under human influence in the foothills of Darjeeling. Himalayan Paryavaran, vol. 3, no. 1 , pp. 18-21.

Jana M.M., DutTA M., 1995. Bank erosion: Its nature, causes and impact in river Balason. Indian Journal of Landscape Systems and Ecological Studies, vol. 18, no. 1, pp. 32-48.

Kondolf G.M., 1994. Geomorphic and environmental effects of instream gravel mining. Landscape and Urban Planning, vol. 28, no. 2-3, pp. 225-243.

Kondolf G.M., 1997. Hungry water: Effects of dams and gravel mining on river channels. Environmental Management, vol. 21, no. 4, pp. 533-551.
LOPEZ J.L., 2004. Channel response to gravel mining activities in mountain rivers. Journal of Mountain Science, vol. 1, no. 3, pp. 264-269.

Martin-Vide J.P., Ferrer-Boix C., Ollero A., 2010. Incision due to gravel mining: Modelling a case study from the Gallego river, Spain. Geomorphology, vol. 117, pp. 261-271.

RINALDI M., WYŻGa B., SurIAN N., 2005. Sediment mining in alluvial channels: Physical effects and management perspectives. River Research and Applications, vol. 21, no. 7, pp. 805-828.

SCHumm S.A., 1977. The fluvial system. New York: John Wiley \& Sons.

Starkel L., Froehlich W., 2000. Channel changes in mountain valleys of various orders [in:] L. Starkel, S.R. Basu (eds.), Rains, landslides and floods in Darjeeling Himalayas. New Delhi: Indian National Academy of Sciences, pp. 137-141.

TAMANG L., 2013. Quarrying activities along the lower Balason River in Darjeeling District, West Bengal. Indian Journal of Spatial Science, vol. 4, no. 1, pp. 1-8.

TAmang L., Mandal D.K., 2010. Changing fluvial characteristics in the Lower Balason River, West Bengal. Geographical Review of India, vol. 72, no. 1, pp. 10-19 
http://rcin.org.pl 